\section{Teaching the Teachers.}

Until the year 1762 the Jesuits had the education of France almost entirely in their hands, and when, therefore, their expulsion was decreed in that year, it was only a necessary step to create an institution to teach the future teachers of France. Here, then, we had the École Normale in theory; but it was a long time before this theory was carried into practice, and very probably it would never have been had not Rolland d'Erceville made it his duty, for more than twenty years, by numerous publications, amongst which is especially to be mentioned his "Plan d'Education," printed in 1783 , to point out, not merely the utility, but the absolute necessity for some institution of the kind. As generally happens in such cases, this exertion was not lost, for, in 1794, it was decreed that an École Normale should be opened at Paris, "ou seront appelés de toutes les parties de la République, des citoyens déjà instruits dans les sciences utiles, pour apprendre, sous les professeurs les plus habiles dans tous les genres, l'art d'enseigner."

To follow these courses in the art of teaching, one potential schoolmaster was to he sent to Paris by every district containing 20,000 inhabitants. 1400 or 1500 young men, therefore, arrived in Paris, and in 1795 the courses of the school were opened first of all in the amphitheatre of the Museum of Natural History. The professors were chosen from among the most celebrated men of France, the sciences being represented by Lagrange, Laplace, Haüry, Monge, Daubenton, and Berthollet.

While there was this enormous progress abroad, represented especially by the teaching of science in Germany and the teaching of the teachers in France, things slumbered and slept in Britain. We had our coal and our iron, our material capital, and no one troubled about our mental capital-least of all the universities, which had become, according to Matthew Arnold (who was not likely to overstate matters), mere hauts lyckes, and "had lost the very idea of a real university," and since our political leaders generally came from the universities little more was to be expected from them.

Many who have attempted to deal with the history of education have failed to give sufficient prominence to the tremendous difference there must necessarily have been in scientific requirements before and after the introduction of steam power.

It is to the discredit of our country that we, who gave the perfected steam engine, the iron ship, and the locomotive to the world, should have been the last to feel the next wave of intellertual progress.

All we did at the beginning of the century was to found mechanics' institutions. They knew better in Prussia, " a bleeding and lacerated mass,".2 after Jena (1 806), King Frederic William III. and his councillors, disciples of Kant, founded the University of Berlin, "to supply the loss of territory by intellectual effort." Among the universal poverty money was found for the Universities of Kœnigsberg and Breslau, and Bonn was founded in 1818. As a result of this policy, carried on persistently and continuously by successive Ministers, aided by wise councillors, many of them the products of this policy, such a state of things was brought about that not many years ago $\mathrm{M}$. Ferdinand Lot, one of the most distinguished educationists of France, accorded to Germany "a supre macy in Science comparable to the supremacy of England at sea."

But this position has not been obtained merely by founding new universities. To Germany we owe the perfecting of the methods of teaching Science.

I have shown that it was in Germany that we find

1 "Schools and Universities on the Continent," p. $29 x$.

2 "University Education in England, France and Germany," Sir Rowland Blennerhassett, p. 25.

NO. I 51 I, VOL. 58] the first organised science teaching in schools. About the year 1825 that country made another tremendous stride. Liebig demonstrated that science teaching, to be of value, whether in the school or the university, must consist to a greater or less extent in practical work, and the more the better; that book work was next to useless.

Liebig, when appointed to Giessen, smarting still under the difficulties he had had in learning chemistry without proper appliances, induced the Darmstadt Government to build a chemical laboratory in which the students could receive a thorough practical training.

It will have been gathered from this reference to Liebig's system of teaching chemistry, that still another branch of applied science had been created, which has since had a stupendous effect upon industry; and while Liebig was working at Giessen, another important industry was being created in England. I refer to the electric telegraph and all its developments, foreshadowed by Galileo in his reference to the "sympathy of magnetic needles."

Not only then in chemistry, but in all branches of science which can be applied to the wauts of man, the teaching must be practical-that is, the student must experiment and observe for himself, and he must himself seek new truths.

It was at last recognised that a student could no more learn Science effectively by seeing some one else perform an experiment than he could learn to draw effectively by seeing some one else make a sketch. Hence in the German Universities the Doctor's degree is based upon a research.

Liebig's was the fons et origo of all our laboratoriesmechanical, metallurgical, chemical, physical, geological, astronomical, and biological. J. NORMAN LOCKYER.

\section{(To be continued.)}

\section{OPENING OF THE THOMPSON.YATES LABORATORIES AT UNIVERSITY COLLEGE, LIVERPOOL.}

THE latest addition to the noble series of buildings now fast surrounding the old lunatic asylum in which University College, Liverpool, started work seventeen years ago is devoted to the Schools of Physiology and Pathology. The professorships in these subjects were endowed and equipped by the late Mr. George Holt some years ago; and now suitable laboratories, on a magnificent scale, have been erected by the generosity of the Rev. S. A. Thompson-Yates at a cost of nearly $30,000 l$.

The building is of Liverpool grey brick and Ruabon terra-cotta in the renaissance Gothic style. It is L-shaped, one wing extending towards the north, where it joins the pathological museum of the old medical school buildings, and the other towards the east, the entrance being at the angle where the wings join. There are three floors and a basement. The two upper floors are occupied by physiology, under Prof. Sherrington; and the ground floor and basement by pathology, under Prof. Boyce. A large lecture theatre, the fine staircase and halls, and a few other apartments for the use of students are common to the two departments. Simplicity of plan has been the aim of the architects (Messrs. A. Waterhouse and Son), and there has been little or no expenditure of space in corridors and passages. As some of the rooms are to accommodate large numbers of workers, and so require to be lofty, while others are the private studies of individuals where a high ceiling would mean waste of space, a free use has been made of the expedient of mezzanines, by which the smaller rooms have been interpolated between the floors. 'The lecture theatre is very completely fitted for lantern illustration, including the projection microscope, the chromoscope, the 
animatograph, the episcope and skiopticon, and also very perfect arrangements for the projection of the spectrum. The Physiological Department contains, in addition, large rooms for:-Chemical physiology with separate workplaces for over fifty students, and fuller accommodation for about six research workers; physical physiology enabling a class of more than thirty to carry out exercises on muscle and nerve at one time, each student's place being provided with electric light, water, gas, electric wire for supply of current, induction coil, electric battery, recording drum driven by fixed pulleys from the shafting running above the table, electric keys, and heliostat apparatus, \&c. ; histology with accommodation for about eighty students, with adjoining preparation and store rooms ; also smaller chemical rooms, professor's private and photographic rooms, room for experiments in electrophysiology, and a smaller theatre for the demonstration of experiments. The Pathological Department has large rooms for:-Morbid histology with work-places for sixty students; bacteriological work with suction and force pumps for filtering, a bacterial mill for pulverising bacteria, and a plentiful supply of steam at high pressure to conduct the various boiling operations. There are also rooms for chemical pathology, museum preparator's work, incubators at constant temperature, private experimental work, pathological diagnosis society, bacteriological work of the city, gas analysis, and the professors' private rooms. Briefly stated the special features of the pathological laboratories are the impervious opaline slabs covering the tops of the work-benches, and diminishing the risk of contamination and facilitating cleaning, the use of steam for boiling operations, a plentiful electric supply working the lamps and the numerous motors, and a specially high-pressure water supply, and lastly the refrigerator chamber. Throughout the Thompson-Yates laboratories are fitted up in the most complete and perfect manner, both for teaching and research; and the favourable opinions which have been so freely expressed by the distinguished scientific visitors during the opening and following days may be briefly summed up in the quotation from Prof. Michael Foster's happy and stimulating speech at the banquet, that "they (the laboratories) produced two physiological effects-they took one's breath away, and they made one's mouth water."

The invitation from the Council and Senate of University College to the opening function was accepted by a large number of distinguished men of science and representatives of universities and medical schools from all parts of the country, including Lord Lister and Lord Kelvin, Earl Spencer and the Earl of Derby, the Bishops of Ripon, Carlisle, Chester and Liverpool, Prof. Virchow, Sir S. Wilks (President of the College of Physicians), the Vice-Chancellor of Cambridge University, Prof. M. Foster and Prof. Hurdon Sanderson, the Presidents of the Royal College of Physicians and Surgeons of Edinburgh, Sir W. Turner, Sir W. Gairdner, Sir Douglas Galton, Sir A. Geikie, Sir J. Crichton Browne, Mr. R. I3. Häldane, M.P., Mr. Justice Kennedy, Sir James Russell, Prof. Rutherford, Dr. Lauder Brunton, Captain Abney, Prof. Rücker, Prof. Poulton, Prof. Gotch, Prof. Kanthack, Sir R. Thorne Thorne, Prof. Schäfer, and many others. These guests, for the most part in their academic robes, walked in procession with the civic authorities, the University and College staff, forming a ceremonial that for stateliness, brilliance, and interest has probably never been equalled before in Liverpool.

The scientific and medical guests arrived in Liverpool on Friday, and that day and Sunday were given up to private hospitality and informal meetings at the College and elsewhere; while Saturday, October 8, was the date of the University Degree ceremony and the formal opening of the new laboratories.

The University function was arranged to take place in St. George's Hall ; and there, in the presence of the Lord Mayor and Corporation, the staff, graduates and students of the University, the distinguished guests, and a large concourse of citizens of Liverpool, the honorary degree of Doctor of Science was conferred upon Lord Lister by Earl Spencer, the Chancellor of the Victoria University.

Lord Lister was presented for the degree by Dr. Richard Caton, Chairman of the Medical Faculty, and formerly Professor of Physiology in University College ; and both the Chancellor and Dr. Caton in their speeches drew attention to Lister's immortal life-work in the antiseptic methods of surgery, and to the benefits conferred thereby upon humanity and the lower animals.

After L.ord Lister had been admitted to the degree by the Chancellor, and had signed the roll of graduates, the Principal of University College (Mr. R. T. Glazebrook, F.R.S.) made a statement as to the history of the medical school and of the erection of the new laboratories by $\mathrm{Mr}$. Thompson-Yates. The generous donor himself was unable to be present, but a letter from him was read expressing good wishes.

Lord Lister then delivered a short address, for which a vote of thanks was proposed by the Lord Mayor of Liverpool, and seconded (in the absence of Lord Derby) by Mr. W. Rathbone, Vice-President of the College.

Lord Lister pointed out in eloquently simple language the necessity for such laboratories in medical education, their inportance both in teaching and research, and the benefits they were calculated to confer upon the College, upon Liverpool, and upon the neighbourhood. Lord Lister then, with a boldness and wisdom which compelled adiniration, made a dignified statement as to the utility and humanity of experiments upon animals, which coming from such a man on such an occasion cannot but have a most beneficial effect. He concluded this part of his address with the sentence, "While I deeply respect the humane feelings of those who object to this class of inquiry, I assure them that, if they knew the truth, they would commend and not condemn them."

After the function in St. George's Hall, the company proceeded to University College, where the brief ceremony of declaring the laboratories open was performed by Lord Lister, after the presentation of a key in a silver casket had been made by the Chairman of the College Council. A similar key was retained for presentation to Mr. Thompson-Yates. Lord Lister and the large assembly of invited guests were then conducted in parties through the laboratories; other parts of the College were also visited. Tea and refreshments were served in the Victoria building ; and, finally, the Lord Mayor's banquet at the Town $\mathrm{Hall}$ in the evening brought to a conclusion the formal proceedings of what stands out as the first great University function in Liverpool.

College functions have been frequent ; noble buildings and new laboratories belonging to L'niversity College have been opened before; but now for the first time the professors and students appeared not merely as members of the College, but of the Victoria University. Liverpool is to be congratulated not only upon the splendid new laboratories, not only upon the impressive ceremonial of their inauguration, but also upon the fact that the first honorary degree conferred by her University, in the City, has been bestowed upon such a man as Lord Lister.

\section{THE OPENING ADDRESSES AT THE} $M E D I C A L$ SCHOOLS.

$\mathrm{I}$ respect of an opening address there seems at the medical schools no fixed rule ; in some cases the first year's student plunges in medias res, and the first word he receives from his teachers is actually work; in others a more or less philosophical discourse, often, it must be 